AJEB

6,1

50

Received 15 April 2021

Revised 3 July 2021

18 August 2021

Accepted 24 August 2021

\section{Risk-taking behavior, competition, diversification and performance of frontier and emerging economy banks}

\author{
Nicholas Addai Boamah, Augustine Boakye-Dankwa and
Emmanuel Opoku \\ Nicholas Addai Boamah, Augustine Boakye-Dankwa and
Emmanuel Opoku
nting and Finance, Kwame Nkrumah University of Science and Technology, \\ Nicholas Addai Boamah, Augustine Boakye-Dankwa and
Emmanuel Opoku
Accounting and Finance, Kwame Nkrumah University of Science and Technology, \\ Kumasi, Ghana
}

\begin{abstract}
Purpose - The study examines the dynamic association between competition, risk-taking, performance and income diversification of frontier and emerging economy (FEE) banks. It additionally, explores the effect of banking sector depth and economic performance on the level of competition, performance and risk-taking behavior of banks in these economies.

Design/methodology/approach - The paper adopts a panel vector auto-regressive technique and collects data across ninety (90) FEEs.

Findings - The paper finds that competition increases with improvement in the depth of the banking sector, a surge in risk-taking behavior and the adoption of focused strategy by banks. Similarly, income diversification activities are driven by competition, banking sector depth, the state of the economy and bank performance. Additionally, risk-taking behavior, banking sector depth and the state of the economy are relevant in describing bank performance. Also, risk-taking behavior is influenced by bank performance, banking sector depth and economic growth.

Originality/value - The evidence indicates that although competition improves banking sector health, excessive competition and non-competitive banking environment constrain banks' performance and stability. Keywords Income diversification, Emerging markets, Bank stability, Moral hazard, Banks intermediation Paper type Research paper
\end{abstract}

\section{Introduction}

The study examines the relationship among risk exposure, competition, diversification and the performance of frontier and emerging economies (FEEs) banks. Banking sector performance is essential for the economic growth of nations. Bank growth and effective banking system drive improvements in an economy (Barth et al., 2004; Morshirian and Wu, 2012; Koivu, 2012; Rahman et al., 2015; Tan, 2018) and influence money market development substantially (Akter et al., 2019). An efficient intermediation by banks and enhanced banks performance thus result in efficient resource allocation to the productive sectors of an economy, productivity improvements and enhancement in social well-being.

Banks' ability to efficiently allocate resources may be influenced by competition, risktaking incentives and income diversification activities. These factors have implications for systemic risk and efficient resource allocation. They impact on the intermediation effectiveness and performance of banks (García-Herrero et al., 2009; Rahman et al., 2015;

(C) Nicholas Addai Boamah, Augustine Boakye-Dankwa and Emmanuel Opoku. Published in Asian Journal of Economics and Banking. Published by Emerald Publishing Limited. This article is published under the Creative Commons Attribution (CC BY 4.0) licence. Anyone may reproduce, distribute, translate and create derivative works of this article (for both commercial and non-commercial purposes), subject to full attribution to the original publication and authors. The full terms of this licence may be seen at http://creativecommons.org/licences/by/4.0/legalcode
Asian Journal of Economics and Banking

Vol. 6 No. 1,2022 pp. $50-68$

Emerald Publishing Limited e-ISSN: 2633-7991

p-ISSN: 2615-9821

DOI 10.1108/AJEB-04-2021-0047

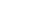


Merin, 2016). In sum, excessive risk-taking and extreme competition may render banks less profitable and raise the likelihood of bank failure (Campbell, 2007; Majumder and Uddin, 2017; Akter et al., 2018). On the other hand, minimal competition and risk aversion may be harmful to bank survival. That is, whereas risk-taking is essential for improved bank performance, excessive risk-taking however may threaten bank survival and soundness.

Banking sector competition may improve bank's performance, enhance efficiency and provide social welfare gains to an economy. That is, the extent of competition and the efficiency of the banking system affect the success of bank's intermediation function and its associated social welfare gains. As Bikker (2010) and Mlambo and Ncube (2011) suggest, healthy competition minimizes monopoly and inefficiency. That is, whilst competition is necessary for bank growth and stability, excessive competition could undermine banks solvency.

Despite the importance of the banking system to economic growth, very little is known about the relationship among risk-taking incentives, competition, diversification and the performance of frontier and emerging markets banks. The interactions among these factors have implications for the soundness, stability and the success of the intermediation role of FEE banks. Risk-taking and competition for instance, influence efficient resource allocation by banks. Exploring the dynamic relationship among these factors in FEE context will go a long way in enhancing our understanding of these uniquely characterized banks and their diversification opportunities for global investors. This may improve the flow of global capital to FEEs and also, promote the efficiency and performance of their banking sectors. For instance, the inflow of global capital may reduce intermediation cost and increase competition (Clarke et al., 2001); expand the funding opportunities available to firms (Kasman and Carvallo, 2014; Zhao et al., 2010); and strengthen shareholder rights and market discipline (Schaeck and Cihak, 2012).These may lead to efficient resource allocation and economic progress.

The evidence on the relationship amongst diversification, competition, risk-taking and the performance of FEE banks is limited and inconclusive. For example, whereas Petria et al. (2015) observe a positive influence of competition on performance, Tan and Floros (2014) find a negative relationship among them. Additionally, Tan (2016), Tan and Floros (2012) and Garcia-Herrero et al. (2009) observe an insignificant influence of competition on bank performance. Similarly, Brissimis et al. (2008) find a positive association between bank risks and its performance although, Majumder and Uddin (2017) and Majumder and Li (2018) observe a negative relationship among them. Thus, the debate on the dynamic engagement between these factors remains unsettled. Additionally, there is paucity of evidence on the relationship among risk-taking, diversification and competition.

The present study therefore builds on the few prior studies (see e.g. Scott and Dunkelberg, 2010; Anginer et al., 2014; Tan, 2016) and examines the dynamic relationship among risktaking, competition, risk diversification and the performance of banks in ninety (90) FEEs. The extended data improve the efficiency of this study's estimates. In addition, the results may be applicable to a wide range of frontier and emerging markets. The findings of studies that focus on a single country or few countries (see e.g. Goddard et al., 2004; Akter et al., 2018, 2019) may not be applicable to a larger FEEs context. The extended cross-country data may contribute in resolving the disparity in existing evidence. In addition, the study contributes to the FEEs banking literature. The evidence is relevant to frontier and emerging markets policy makers and banking practitioners.

The study provides evidence that banking sector depth, risk-taking behavior of banks and economic growth describe competition. In addition, bank performance is driven by banking sector depth, risk-taking incentives and the state of the economy. Also, the growth in banking sector depth, banks performance and economic growth affect the risk-taking behavior of banks. Additionally, diversification decreases as competition, profitability and banking
Frontier and emerging economy banks 
AJEB

6,1

\section{2}

sector depth increase, but increases with inflation growth. In addition, focused strategy is more beneficial than diversification strategy. The findings show that competition, risk-taking behavior and banking sector depth Granger cause bank performance; risk-taking and banking sector depth cause competition; and performance, competition, banking sector depth and risk-taking cause diversification.

The remainder of the paper is structured as follows. Section 2 reviews the extant literature. The discussion of methodology and data are presented in sections 3 and 4, respectively. The empirical evidence is discussed in section 5, whereas conclusions are presented in section 6 .

\section{The related literature}

Gupta and Moudud-U1-Huq (2020) investigate the dynamic association between income diversification, competition and risk-taking among BRICS banks. By employing a two-step system generalized methods of moments (2GMM), they note a positive relationship between competition and risk-taking behavior. Additionally, they find that income diversification influences the risk-taking behavior of banks negatively. The authors observe a non-linear association between competition, revenue diversification and bank risk-taking incentives. Similarly, González et al. (2017) explore the relationship between competition and bank stability for Middle East and North Africa (MENA) banks. González et al. measure competition by the Herfindhal index and the $H$-statistic (HST) and apply a dynamic panel model in a generalized method of moments (GMM) estimation framework. They observe a Ushaped relationship between competition and risk-taking behavior of banks in the MENA countries.

Recently, Saif-Alyousfi et al. (2020) examine the impact of competition and concentration on the risk-taking behavior and stability of banks in Gulf Cooperation Council (GCC) countries. By using a dynamic panel model and a GMM estimation technique, they observe that rising competition and concentration lead to financial fragility. Additionally, declining competition and asset concentration promote risk-taking among less capitalized, less liquid and small banks which may raise banking sector fragility. In a related study, Maji and Hazarika (2018) adopt the HST, Herfindahl-Hirschman index and concentration ratio as proxies for competition. Using a three-stage least squares (3SLS) framework, they find that the effect of competition on risk-taking and stability is respectively positive and negative. Recently, Sarkar and Sensarma (2016) argue that asset concentration reduces credit, market and asset risks although, it worsens capital and liquidity risks of Indian banks. Their findings imply that appropriate level of competition is desired for bank success.

Tan (2016) employs the Lerner index and Herfindahl-Hirschman index as surrogates for competition. Adopting a one-step GMM system estimator, Tan notes an insignificant influence of competition and risk on bank performance. The author attributes this to significant State intervention in the Chinese banking sector via capital injections. Tan's evidence suggests that State interventions could undermine competition in the banking system, thereby protecting inefficient institutions. This may create moral hazard problems and encourage excessive risk-taking. In a related study, Scott and Dunkelberg (2010) explore the effect of competition on the risk and performance of banks. Relying on a survey of small business owners, they find that concentrated markets are less competitive. Additionally, they note a positive relationship between competition and banking experience of customers. Also, increased competition enhances credit and non-credit ratings of banks. That is, competition minimizes the level of risk in the banking system. Similarly, Akter et al. (2018) investigate the effect of bank risk-taking and capital regulation on performance using a two-step system GMM estimator. They argue that excessive risk-taking impacts negatively on profitability.

Recently, Schaeck and Cihák (2014) using the Boone indicator as a measure of competition and a two-step GMM technique, observe a positive and negative effects of competition on 
risk-taking and profitability, respectively. Their evidence shows that competition enhances bank stability, however, it affects the stability of stronger banks more than weaker ones. The authors argue that competition affects risk-taking incentives, performance and banks stability via the efficiency channel. Their findings suggest that competition is good for the health of banks and the entire banking system although it may be less beneficial to fragile banks. Schaeck and Cihák's (2014) finding is in agreement with Sarkar and Sensarma's (2016) evidence.

Tabak et al. (2012) examine the effect of competition on the risk-taking behavior of Latin American banks. They show that competition affects risk-taking behavior in a non-linear way. Their evidence indicates that competition minimizes risk-taking and in essence, enhances financial stability. Additionally, limited competition encourages risk-taking and undermines financial stability. They argue that bank size and capitalization may explain the non-linear relationship between competition and risk-taking. Similarly, Jiménez et al. (2013) investigate the effect of competition on banks' risk-taking incentives in the Spanish banking sector. They observe a non-linear relationship between market concentration and risk-taking in the deposits and loans market. They find support for the franchise value hypothesis in the loans market. In a related study, Soedarmono et al. (2013) observe that the risk-taking tendencies of Asian banks decrease with increasing market competition. This they observe, result in declining loan losses and stable banking system. Corroborating, Fiordelisi and Mare (2014) find that European cooperative banks assume more risk in less competitive markets.

Anginer et al. (2014) employ a co-dependence technique to examine the correlations in the risk-taking incentives of banks. By adopting various measures of competition including the Lerner index and the HST, they find a negative association between bank competition and systemic risk. Also, rising competition leads to risk diversification and improves the soundness of the banking system. In addition, weak supervision and private monitoring, government ownership of banks and anti-competitive public policies lead to correlated risktaking and undermine the soundness of the banking system. The authors argue that efficient public and private monitoring of banks lessens the negative effect of limited competition on banking sector fragility.

In a study of the Barbadian banking system, Craigwell and Maxwell (2006) investigate the effect of income diversification on bank performance. The authors suggest that Barbadian banks have less diversified income. Additionally, diversification improves banks performance and raises earnings volatility. Their findings suggest that participation restrictions and limited technology adaptation lead to lower levels of diversification. Quite recently, Berger et al. (2010) examine the effect of focus and diversification strategies on banks' performance. They argue that diversification leads to reduced performance. The authors suggest that foreign participation and links with conglomerates moderate the relationship between diversification, profitability and costs. Additionally, diversification discounts are partly the outcome of limited managerial expertise or ineffective incentive packages for managers. Recently, Ghosh (2014), by employing 3SLS estimation, suggests that lesser degree of income diversification is associated with higher risk levels.

The evidence from the literature suggests a dynamic engagement between bank competition, efficiency, risk-taking, diversification and performance. This may be explained by theories such as the market power theory (MPT) and the efficient structure theory (EST). The MPT posits a connection between market power, product diversification and bank performance. The theory suggests that market power or lesser degree of competition leads to higher profit margins. For instance, the structure-conduct-performance hypothesis (SCPH) of the MPT argues that concentration enables banks to collusively set higher prices and consequently earn supernormal profits. The SCPH suggests that market structure influences bank behavior and consequently performance. The relative-market power hypothesis (RMPH) of the MPT, however, argues that banks with larger market share and diversified
Frontier and emerging economy banks 
AJEB

6,1

\section{4}

products acquire significant market power which enables them to influence prices and profitability. The MPT thus suggests interactions among competition, bank size, diversification and performance.

Similarly, the EST, proposed by Demsetz (1973) and extended by Berger (1995) to the $X$ efficiency and scale-efficiency hypotheses, sheds insights into the nexus between bank efficiency, competition and performance. The theory suggests that higher levels of cost and/ or scale efficiency improves banks' performance and leads to larger market share and higher concentration. The $X$-efficiency hypothesis argues that management quality and enhanced practices deliver cost savings gains and consequently improve bank performance. The scaleefficiency hypothesis, on the other hand, links better bank performance to improved scale of operation and its associated cost reduction gains.

In sum, the market power (MPT) and the efficient structure (EST) theories point to a dynamic interaction between bank efficiency, risk-taking, competition, diversification and performance. The nature of the interaction between these variables may not be straightforward. As the theories imply, less competition may lead to higher profits due to collusive behavior of banks. On the other side, higher competition may improve efficiency and minimizes risk-taking thereby exerting positive effect on bank performance.

\section{Methodology}

The study adopts Equation (1), a panel-vector autoregressive (panel-VAR) model to examine the relationship among competition, performance, risk-taking and diversification of frontier and emerging markets banks. Equation (1) incorporates the growth in banking sector depth (DBAG), growth in gross domestic product (GDPG) and growth in average consumer price index (CPIG) as control variables. A panel-VAR specification is appropriate as it models the variables as an evolutionary process of the prior period's values, lagged values of other variables in the system and an error term. Thus, the panel-VAR technique helps in capturing both dynamic and static interdependencies, deals with potential endogeneity problems and ensures estimation efficiency by fitting the models as a system of equation (see e.g. HoltzEakin et al., 1988; Canova and Cicarelli, 2013). Although, a GMM approach likewise deals with endogeneity and unobserved heterogeneity problems, we prefer panel-VAR due to its efficiency gains.

$$
\begin{aligned}
\sum_{k=1}^{n} Y_{i, t}^{k} & =\sum_{k=1}^{n} \alpha_{k}+\sum_{k=1}^{n} \sum_{j=1}^{v} \beta_{k, j} Y_{i, t-j}^{k}+\varepsilon_{i, t}^{k} \\
\alpha & =\text { intercept, } \varepsilon=\text { errorterm } .
\end{aligned}
$$

$Y=N \times T$ matrix consisting of return on assets (ROA), provision for non-performing loans (PNPLs) or non-performing loans ratio (NPL), top five (5) banks asset concentration (COM) or the HST, growth in banking sector depth (DBAG), growth in gross domestic product (GDPG), growth in average consumer price index (CPIG) and diversification (NII). The superscript $k$ and subscripts $i$ and $j$ respectively represent the variables (elements of $Y$ ), country and the lag length.

Our proxies for competition, performance and diversification are respectively the HST or top five (5) banks asset concentration (COM), the ROA or net interest margin (NIM) and banks non-interest income to total income (NII). We measure banking sector depth by the growth in deposit money banks assets to GDP (DBAG), risk-taking by the non-performing loans ratio (NPL) or the provisions for non-performing loans (PNPL). We follow prior studies such as Liu et al. (2012), Sarkar and Sensarma (2016), Zheng et al. (2017) and Li (2019) and measure competition by the HST. This measure of competition is appropriate as it measures the elasticity of bank interest revenues to input prices (Danisman, 2018), relies on bank-level data 
to measure competition (Liu et al., 2012) and permits comparison across banks of different size and specializations (Claessens and Laeven, 2004). We adopt COM as an alternative measure of competition since asset concentration signals market power. Thus, the concentration of assets in fewer banks implies significant market power by those banks and therefore, minimal level of competition in the banking sector. In addition, we incorporate a one year lag of the endogenous variables in Equation (1). A lag length of more than a year may be less meaningful in describing the time series and cross-sectional variations in the dependent variables. For instance, banking sector competition, risk-taking or growth in inflation at time $t-2$ and beyond may not appropriately describe the variability in diversification or performance at time $t$. A longer lag length may introduce noise in system. A one year lag length appears most appropriate for the nature of the variables under study.

\section{Data and descriptive statistics}

The study collects banking sector data across ninety (90) FEEs over the period 2000 to 2015. It relies on a balanced panel data which consist of 90 cross-sections and 15 yearly observations for each country. Data on the top five banks asset to total banks asset (COM), domestic bank assets to GDP (DBA), non-performing loans to gross loans (NPL), PNPLs, noninterest income (NII), ROA after tax, NIM and HST are obtained from the Global Financial Development Database [1]. We collected data on consumer price index average prices (CPI) and GDP growth from the World Development Indicators database.

The descriptive statistics of the data are presented in Table 1 . The average/standard deviations of the ROA and NIM are $2 \% / 0.023$ and 5\%/0.029, respectively. Additionally, the average NPL and PNPL of FEE banks are 5.7 and $53.2 \%$ respectively. This appears to be inconsistent with Boateng (2019). The average largest five banks asset concentration ratio $(70.3 \%)$ suggests minimal competition among FEE banks as these large banks may have monopoly power. Also, Table 1 shows that banks in FEEs generally show a higher degree of income diversification with an average NII of 35\%. The skewness and kurtosis show that the variables are generally non-normally distributed.

Table 2 presents the correlation matrix of the studied variables. The table indicates a negative correlation between ROA and NPL/PNPL. This suggests that bank profitability decreases as risk-taking incentives increase. Also, the positive correlation between NIM and PNPL/NPL (Table 2) shows improvement in interest income as risk-taking incentives increase. In addition, there exists a positive correlation between NPL and NII and a negative correlation between NII and PNPL. This evidence may imply that banks diversify their income as loan losses increase. That is, FEE banks largely focus on interest income. These banks however diversify when significant losses are incurred in the loans market.

\begin{tabular}{lccrr}
\hline & Mean & Standard deviation & Skewness & Kurtosis \\
\hline Return on assets after tax (ROA) & 0.020 & 0.023 & -1.313 & 32.234 \\
Net interest margin (NIM) & 0.056 & 0.029 & 1.988 & 15.981 \\
Provision for non-performing loans (PNPL) & 0.532 & 0.559 & 1.821 & 11.962 \\
Non-performing loans (NPL) & 0.057 & 0.077 & 2.322 & 11.482 \\
Top five banks asset concentration (COM) & 0.703 & 0.280 & -1.429 & 4.333 \\
$H$-statistics (HST) & 0.191 & 0.301 & 1.299 & 3.619 \\
Growth in domestic bank assets to (DBAG) & 0.036 & 0.114 & 0.167 & 12.419 \\
Non-interest income to total income (NII) & 0.348 & 0.153 & 0.334 & 3.456 \\
Growth in the average consumer price index (CPIG) & 0.058 & 0.080 & 7.218 & 102.009 \\
GDP growth (GDPG) & 0.081 & 0.131 & -0.897 & 11.465
\end{tabular}

Frontier and emerging economy banks

Note(s): The table presents the descriptive statistics of the data

Table 1. Descriptive statistics 


\begin{tabular}{|c|c|c|c|c|c|c|c|c|c|c|}
\hline \multirow{5}{*}{$\begin{array}{l}\text { AJEB } \\
6,1\end{array}$} & & $\mathrm{COM}$ & NIM & NII & NPL & ROA & HST & PNPL & GDPG & CPIG \\
\hline & $\mathrm{COM}$ & 1 & & & & & & & & \\
\hline & NIM & -0.104 & 1 & & & & & & & \\
\hline & NII & -0.055 & 0.036 & 1 & & & & & & \\
\hline & NPL & -0.100 & 0.018 & 0.045 & 1 & & & & & \\
\hline \multirow{6}{*}{56} & ROA & -0.133 & 0.440 & 0.037 & -0.184 & 1 & & & & \\
\hline & HST & 0.006 & -0.112 & -0.221 & 0.027 & -0.066 & 1 & & & \\
\hline & PNPL & 0.019 & 0.043 & -0.141 & 0.093 & -0.030 & 0.248 & 1 & & \\
\hline & GDPG & 0.022 & 0.122 & 0.149 & -0.142 & 0.222 & -0.128 & 0.016 & 1 & \\
\hline & CPIG & -0.048 & 0.216 & 0.155 & -0.038 & 0.096 & -0.039 & 0.023 & 0.012 & 1 \\
\hline & DBAG & 0.007 & 0.076 & 0.017 & -0.100 & 0.053 & -0.049 & 0.014 & -0.144 & 0.056 \\
\hline
\end{tabular}

Note(s): The Table presents the correlation matrix of the variables for the study. COM, DBAG, NPL, NII, ROA, NIM, CPIG, PNPL, HST and GDPG are the top five banks asset to total banks asset, growth in domestic bank assets to GDP, non-performing loans to gross loans, non-interest income to total income, ROA, net interest

Table 2. margin, growth in consumer price index average prices, provision for non-performing loans, $H$-statistic and GDP growth respectively

The table shows that HST correlates positively with PNPL and NPL and negatively with NIM, NII and ROA. The correlation between HST and PNPL/NPL suggests that increased competition raises risk-taking incentives of FEE banks. Similarly, the correlations between HST and NIM, and ROA and NII show that competition reduces profitability and income diversification. Also, Table 2 indicates a weak negative correlation between concentration ratio and ROA/NIM. This appears inconsistent with Guidara et al. (2013) finding. The association suggests that an increase in concentration may exert negative influence on bank performance. Additionally, the association between COM and NPL is negative, which indicates that decreasing concentration might cause non-performing loans to increase. Most likely, a decrease in concentration leads to an increase in competition which consequently induces banks to create low quality loans. The generally low correlations contained in Table 2 (highest of 0.440) suggest that multicollinearity may have minimal effect on the results of the study.

\section{Empirical results}

Stationary series are essential for the reliability of the tests conducted in this study. We thus examine all the variables adopted in this study for unit root and report the results in Table 3. We adopt the augmented Dicky-Fuller test (ADF) (see Dickey and Fuller, 1979) to examine the variables for unit root with trend. The findings show that all the series are stationary. Therefore, unit root has no effect on the tests conducted in this study.

The results of estimating Equation (1) are presented in Table 4. We rely on the HST and the ROA as proxies for competition and performance, respectively. We investigate the stability conditions of the estimated models using the eigenvalues. The findings recorded in Table 4 indicate that all the eigenvalues are less than 1 . This shows that the estimated models are stable.

Table 4 shows that competition loads positively on the PNPLs, diversification (NII), inflation growth (CPIG) and the growth in banking sector depth (DBAG). It, however, loads negatively on bank performance (ROA), non-performing loans (NPL) and GDP growth (GDPG). The Table shows that bank performance decreases with HST, GDPG, CPIG, NPL and DBAG but improves with PNPL and NII. Aside the PNPL and DBAG coefficients, all the coefficients are insignificant. The impact of these factors on bank performance is thus less meaningful. 


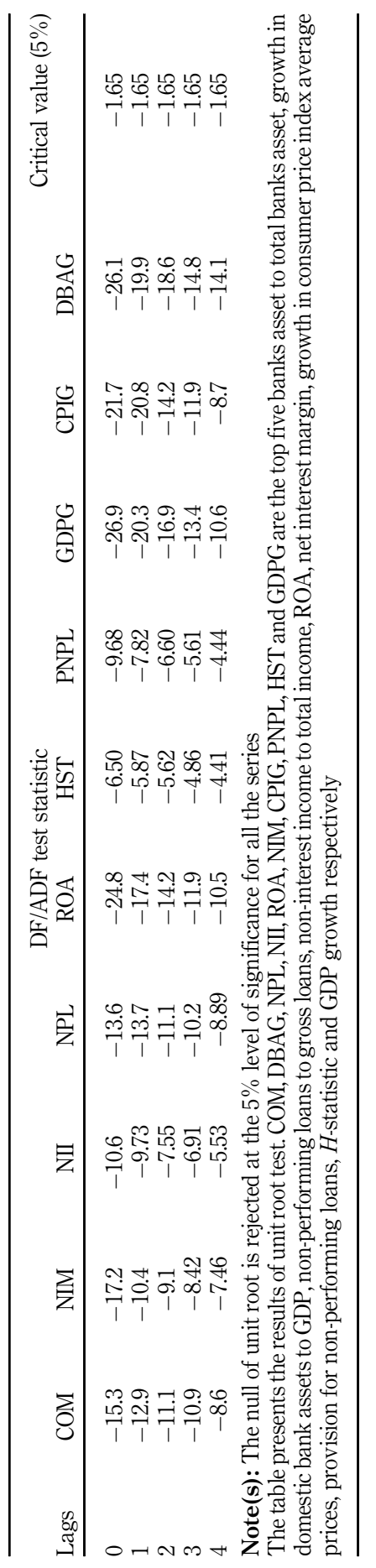

Frontier and emerging economy banks

Table 3. Univariate unit root test 
AJEB
6,1

58

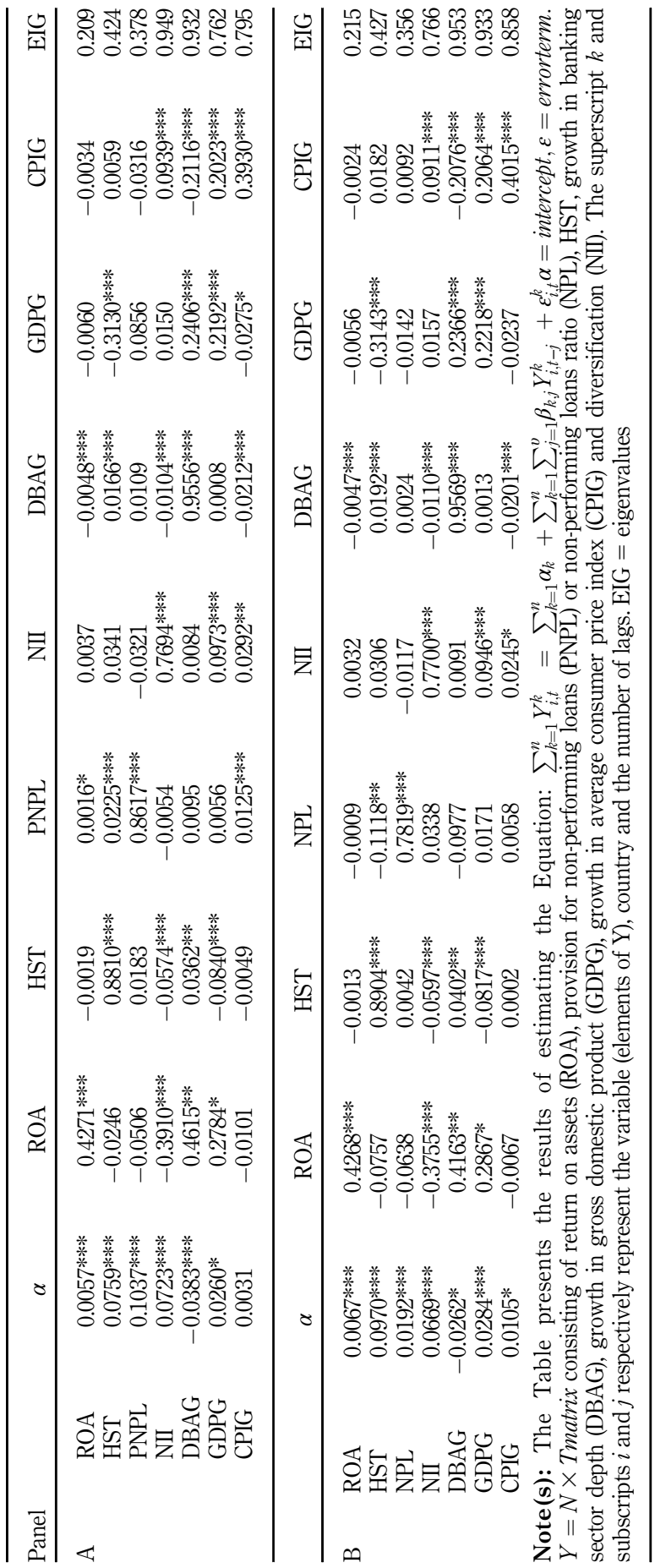

Table 4.

Empirical results 
The evidence suggests that banks increase the PNPLs in an effort to improve performance. That is, banks enhance profitability via increased risk-taking activities. The NII evidence is in agreement with Craigwell and Maxwell (2006) but appears inconsistent with the observations by Berger et al. (2010) and Tan (2016).Also, the finding on the relationship between ROA and HST is consistent with the evidence in prior studies (see e.g.Tan, 2016; Garcia-Herrero et al., 2009; Tan and Floros, 2012). In addition, the negative association between performance and banking sector depth implies that the expansion of FEE banks is associated with intense competition. This subsequently reduces interest income and thus performance. It may also be inferred that banks in FEEs with relatively larger banking sectors are outperformed by their counterparts in economies with smaller banking sectors. It is possible that competition and institutional quality are weaker in FEEs with less developed banking sectors which enable them to realize higher interest margins.

Table 4 indicates that rising competition and growth in domestic banks asset increase the risk-taking incentives (PNPL and NPL) of FEE banks. Also, profitability and diversification drive down the risk-taking tendencies of banks. Additionally, GDP growth dampens nonperforming loans although it influences the PNPLs positively. In addition, competition, profitability and banking sector depth affect income diversification negatively. Also, diversification rises with inflation growth. The evidence suggests that FEE banks may reduce their risk-taking incentives in response to instabilities in the larger economy. Rising inflation may lead to rising interest rates and the likelihood of default which may lead to a decrease in the risk-taking activities of banks. The effect of PNPL and NPL on diversification may imply that FEE banks employ income diversification activities mostly as a risk management technique which is aimed at reducing non-performing loans.

The positive influence of HST on PNPL infers that excessive competition increases bank risk-taking tendencies and undermines the stability and soundness of the banking system. The NII findings imply that profitable FEE banks are less diversified, and that an increase in profitability is associated with declining non-interest income. Thus, the performance of FEE banks is driven mainly by interest income. This implies that profitable FEE banks have higher concentration on interest income and thus are riskier. The findings may also suggest that FEE banks have limited opportunity to diversify off balance sheet. The relationship between diversification and profitability appears to be in consonance with Berger et al.'s (2010) observation that diversification drives profit decline.

The relationship between NPL and GDPG suggests that as FEE banks grow, nonperforming loans decrease. That is, economic well-being reduces loan default. Also, the GDPG influence on PNPL may imply that FEE banks increase the PNPLs in response to economic expansion. This may mean that FEE banks step-up their risk-taking activities in an effort to exploit the opportunities associated with economic growth. Additionally, as the economy improves, demand for loans may increase; banks may thus create more long-term assets or increase risk-taking in an effort to earn higher interest income. Consequently, they increase the PNPLs. This may explain the positive relationship between PNPL and GDPG. Arguably, the demand for bank loans increases during periods of economic expansion; this enables banks to increase their interest income as well as profitability.

We conduct further tests with alternative measures of profitability and competition. Equation (1) is thus re-estimated by measuring profitability and competition respectively by the NIM and the top five (5) banks asset concentration (COM). The results are presented in Table 5. The evidence in Table 5 largely corroborates those of Table 4. Consistent with the findings in Table 4, all the eigenvalues reported in Table 5 are less than 1 . Therefore, the estimated models are stable.

Table 5 indicates that the top 5 banks asset concentration $(\mathrm{COM})$ is influenced positively by DBAG, CPIG and NII. In addition, NIM, NPL, PNPL and GDPG affect COM negatively. The findings show that rising diversification, a surge in inflation and banking sector growth lead
Frontier and emerging economy banks 
AJEB
6,1

60

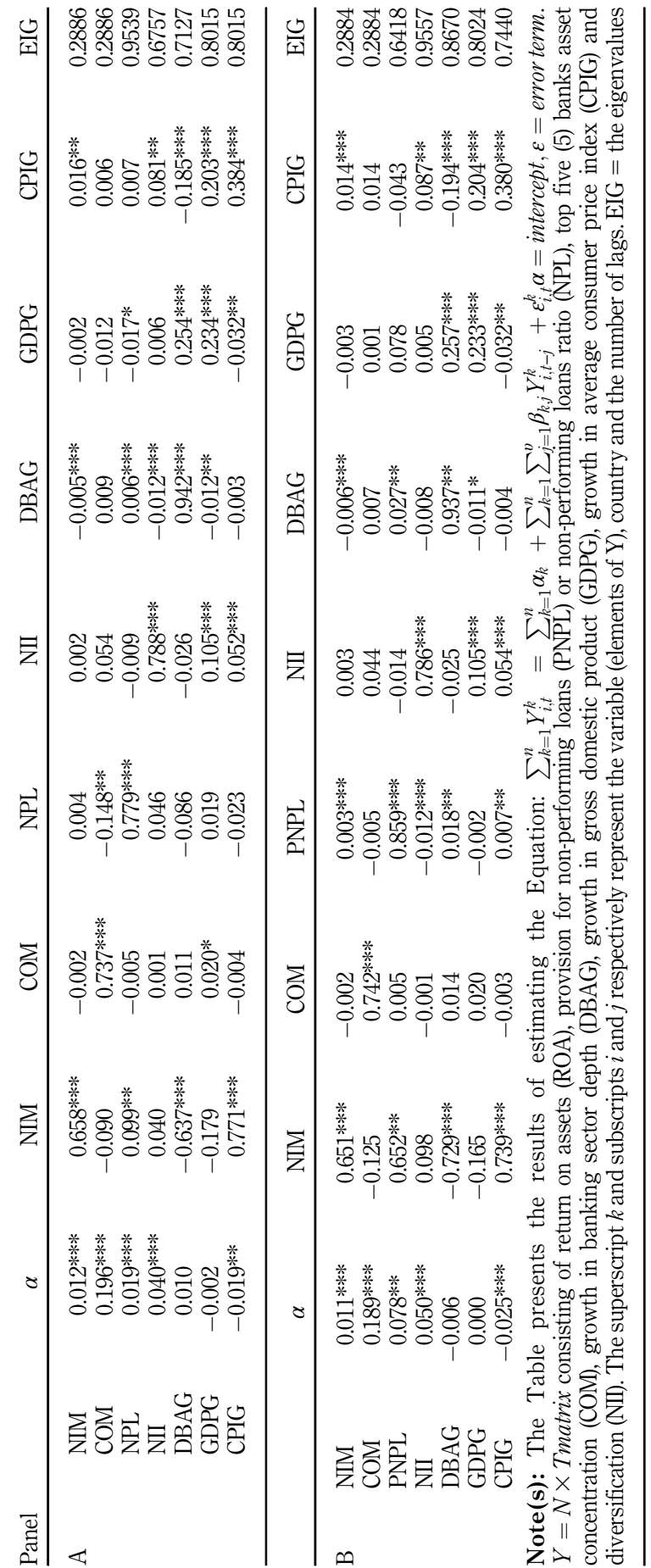

Table 5.

Empirical results 
to asset concentration in few banks. This may increase the market power and the influence of those few banks. Consequently, banking sector competition may be undermined. The effect of NII on COM appears consistent with the relative market power hypothesis which posits that concentration and for that matter market power increases with product diversification. The evidence shows that economic expansion, rising non-performing loans and the PNPLs minimize asset concentration. It is possible that economic expansion boosts the confidence of FEE banks which incentivizes smaller banks to create more assets and eventually enhances banking sector competition. Additionally, the findings may imply that increasing nonperforming loans leads to significant asset losses for the top 5 banks which reduce their market power.

The table provides further evidence that NPL, PNPL and CPIG affect NIM positively. Also, the DBAG impact on NIM is negative. Additionally, NIM impacts on CPIG, NPL and PNPL positively and DBAG negatively. As inflation increases, non-performing loans and the likelihood of default may arguably increase.

In addition, rising non-performing loans suggests higher default risk probabilities. These may explain the positive influence of NPL, PNPL and CPIG on NIM. Banks may demand higher risk premium and expected inflation loadings as compensation for higher default risk and as a means of preserving the real value of their assets respectively. The negative effect of DBAG on NIM may be driven by intense competition and reduced margins as banking sector depth grows. The loadings of DBAG on NIM may suggest that FEE banks improve on their performance through asset growth. The relationship between GDPG and NIM is in agreement with Akter et al. (2018) and Tan's (2016) observations. Also, the positive association between NIM and CPIG is in consonance with Perry (1992) and Tan (2016). Perry for instance, argues that the relationship is due to the ability of banks to appropriately forecast and capture expected inflation in loan interest rates determination thereby transferring the extra cost to borrowers. Shifting the extra cost to borrowers could, however, increase loan default.

Taking together the association between NPL and NII, DBAG and NII, and PNPL and NII, the evidence in Tables 4 and 5 indicates that FEE banks increase the PNPLs in periods of asset growth. That is, banks anticipate the potential increase in non-performing loans and make provisions for it during periods of asset expansion. Also, banks engage in less diversification in periods of asset growth. However, they improve on diversification and reduce asset acquisition as non-performing loans rise. That is, as default risk increases FEE banks focus more on non-interest income. The evidence suggests that banks engage in a trade-off between asset growth and diversification. In addition, the negative influence of HST and COM on ROA and NIM, respectively, implies that a decrease in concentration and/or an increase in competition dampen bank performance. This appears consistent with the structure-conduct-hypothesis which associates improved bank performance to increased concentration and/or lesser degree of competition.

We conduct Granger causality test and present the results in Table 6. The tests permit us to examine the direction of causality between the variables in Equation (1). The evidence indicates that NPL, DBAG, PNPL and GDP Granger cause HST; ROA, HST, DBAG and CPIG cause NII; HST, NIM, COM, CPIG and GDPG cause DBAG; and PNPL, HST, DBAG cause ROA. Similarly, there is a causal effect of NII and DBAG on CPIG; DBAG and CPIG on NIM; and NPL on COM. Additionally, causality is observed from NPL, PNPL and DBAG to COM. Table 6 shows a bi-directional causality between NIM and PNPL, ROA and DBAG, HST and DBAG, and CPIG and DBAG. That is, for these sets of variables, causality could be in any direction.

We estimate the Cholesky forecast error variance decomposition (FEVD) for the estimated models and present the results in Table 7 . The Table indicates that the major drivers of the variance of ROA and HST are, respectively, lagged-ROA $(98.2 \%)$ and DBAG $(0.94 \%)$ and lagged-HST $(98 \%)$ and NII (1.52\%). Similarly, the variation in the variance of NPL is largely

Frontier and emerging economy banks 


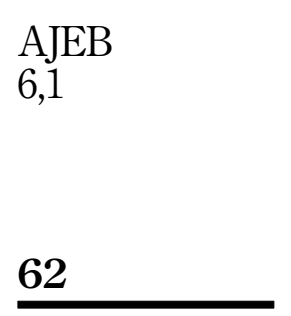

Table 6.

Granger causality test

\begin{tabular}{|c|c|c|c|c|c|}
\hline 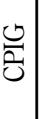 & 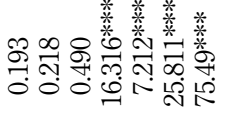 & $\stackrel{0}{0}$ & 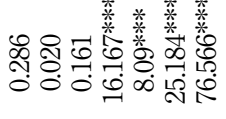 & 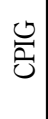 & 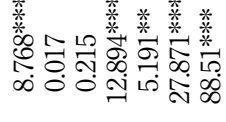 \\
\hline 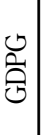 & 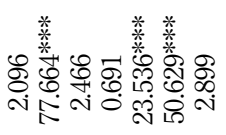 & ثิ & 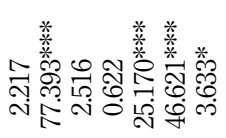 & ڤે & 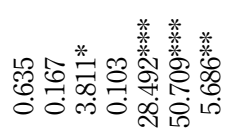 \\
\hline 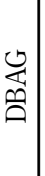 & 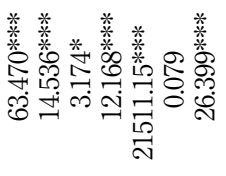 & 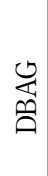 & 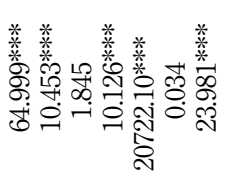 & 悹 & 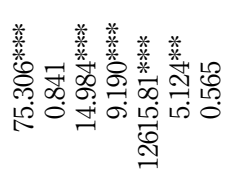 \\
\hline 云 & 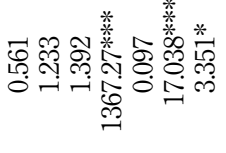 & 具 & 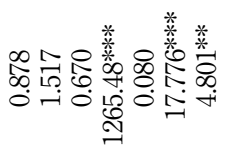 & 完 & 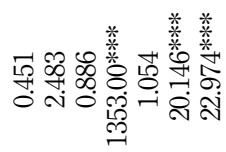 \\
\hline $\overrightarrow{\mathrm{z}}$ & 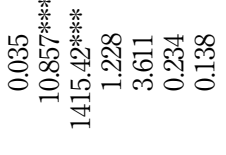 & 完 & 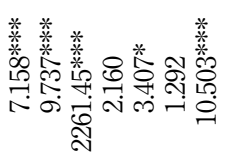 & 完 & 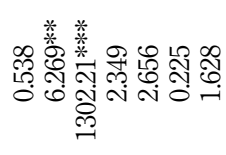 \\
\hline$\stackrel{-\hookrightarrow 口}{\Omega}$ & 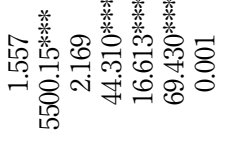 & 昜 & 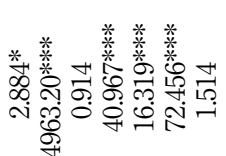 & ¿ & 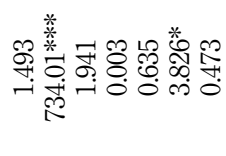 \\
\hline 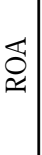 & 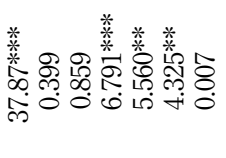 & 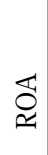 & 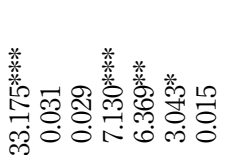 & 㐭 & 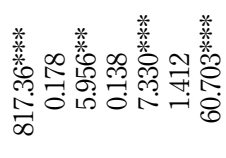 \\
\hline & 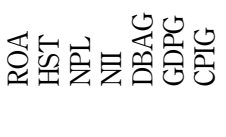 & & 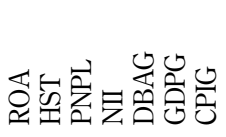 & & 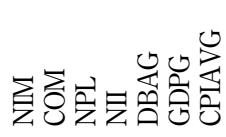 \\
\hline 胥 & $\varangle$ & & $ص$ & & 0 \\
\hline
\end{tabular}




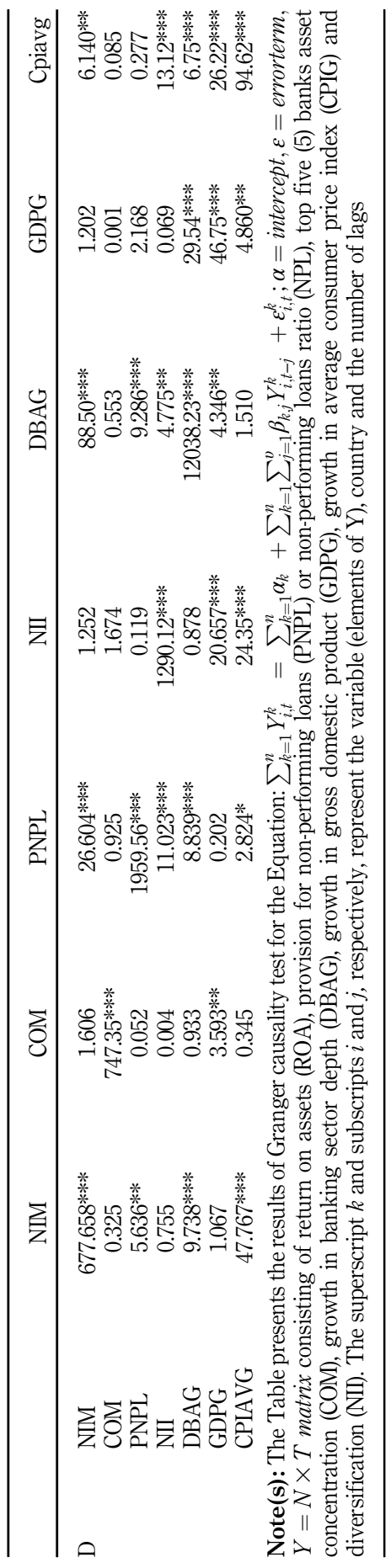

Frontier and emerging economy banks

63

Table 6. 
AJEB
6,1

\begin{tabular}{|c|c|c|c|c|c|c|c|c|}
\hline Panel & & ROA & HST & NPL & NII & DBAG & GDPG & CPIG \\
\hline \multirow[t]{7}{*}{ A } & ROA & 98.19 & 0.21 & 0.07 & 0.29 & 0.93 & 0.29 & 0.02 \\
\hline & HST & 0.12 & 97.98 & 0.04 & 1.52 & 0.26 & 0.08 & 0.00 \\
\hline & NPL & 4.66 & 0.15 & 94.65 & 0.36 & 0.05 & 0.09 & 0.04 \\
\hline & NII & 1.16 & 7.61 & 0.95 & 89.05 & 0.27 & 0.55 & 0.40 \\
\hline & DBAG & 0.73 & 4.19 & 0.07 & 2.50 & 89.84 & 2.60 & 0.07 \\
\hline & GDPG & 3.82 & 3.64 & 1.43 & 1.36 & 0.88 & 87.37 & 1.51 \\
\hline & CPIG & 0.01 & 0.92 & 0.03 & 1.03 & 1.55 & 1.65 & 94.81 \\
\hline
\end{tabular}

\begin{tabular}{|c|c|c|c|c|c|c|c|c|}
\hline & & ROA & HST & PNPL & NII & DBAG & GDPG & CPIG \\
\hline \multirow[t]{8}{*}{ B } & ROA & 98.13 & 0.22 & 0.02 & 0.33 & 0.95 & 0.32 & 0.03 \\
\hline & HST & 0.15 & 97.58 & 0.37 & 1.62 & 0.20 & 0.08 & 0.01 \\
\hline & PNPL & 0.02 & 2.92 & 96.54 & 0.02 & 0.02 & 0.47 & 0.01 \\
\hline & NII & 1.12 & 7.43 & 0.37 & 89.86 & 0.23 & 0.56 & 0.43 \\
\hline & DBAG & 0.76 & 4.05 & 0.50 & 2.44 & 89.54 & 2.63 & 0.08 \\
\hline & GDPG & 3.79 & 3.71 & 0.20 & 1.33 & 0.96 & 88.57 & 1.43 \\
\hline & CPIG & 0.01 & 0.94 & 0.51 & 1.22 & 1.72 & 1.64 & 93.96 \\
\hline & & NIM & $\mathrm{COM}$ & NPL & NII & DBAG & GDPG & CPIG \\
\hline \multirow[t]{8}{*}{$\mathrm{C}$} & NIM & 97.99 & 0.12 & 0.06 & 0.03 & 1.05 & 0.66 & 0.10 \\
\hline & $\mathrm{COM}$ & 0.24 & 98.95 & 0.28 & 0.46 & 0.02 & 0.04 & 0.03 \\
\hline & NPL & 0.20 & 0.04 & 98.94 & 0.41 & 0.23 & 0.16 & 0.02 \\
\hline & NII & 0.70 & 0.95 & 1.32 & 95.72 & 0.31 & 0.67 & 0.32 \\
\hline & DBAG & 13.89 & 1.00 & 0.03 & 4.48 & 77.61 & 2.94 & 0.05 \\
\hline & GDPG & 1.35 & 0.06 & 2.39 & 2.42 & 0.40 & 92.04 & 1.34 \\
\hline & CPIG & 6.99 & 0.10 & 0.09 & 2.03 & 0.13 & 1.05 & 89.60 \\
\hline & & NIM & $\mathrm{COM}$ & PNPL & NII & DBAG & GDPG & CPIG \\
\hline \multirow[t]{7}{*}{ D } & NIM & 97.72 & 0.13 & 0.10 & 0.07 & 1.17 & 0.74 & 0.07 \\
\hline & COM & 0.27 & 99.25 & 0.00 & 0.38 & 0.00 & 0.08 & 0.02 \\
\hline & PNPL & 0.19 & 0.05 & 99.11 & 0.07 & 0.10 & 0.47 & 0.00 \\
\hline & NII & 0.58 & 1.01 & 1.14 & 95.99 & 0.21 & 0.71 & 0.35 \\
\hline & DBAG & 14.27 & 1.00 & 1.30 & 4.02 & 76.35 & 3.00 & 0.06 \\
\hline & GDPG & 1.37 & 0.05 & 0.35 & 2.26 & 0.51 & 94.12 & 1.34 \\
\hline & CPIG & 6.73 & 0.10 & 0.19 & 2.21 & 0.20 & 0.89 & 89.67 \\
\hline
\end{tabular}

Note(s): The Table presents the results of the Cholesky FEVD test for the Equation: $\sum_{k=1}^{n} Y_{i, t}^{k}=\sum_{k=1}^{n} \alpha_{k}+$ $\sum_{k=1}^{n} \sum_{j=1}^{v} \beta_{k, j} Y_{i, t-j}^{k}+\varepsilon_{i, t}^{k} ; \alpha=$ intercept, $\varepsilon=$ errorterm. $Y=N \times$ Tmatrix consisting of return on assets (ROA), provision for non-performing loans (PNPL) or non-performing loans ratio (NPL), top five (5) banks asset

Table 7. concentration (COM), growth in banking sector depth (DBAG), growth in gross domestic product (GDPG), Forecast error variance growth in average consumer price index (CPIG) and diversification (NII). The superscript $k$ and subscripts $i$ and decomposition

$j$ respectively represent the variable (elements of $\mathrm{Y}$ ), country and the number of lags

driven by ROA (4.7\%) and lagged-NPL (94.5\%) whereas that of PNPL is mainly driven by HST $(2.9 \%)$ and lagged-PNPL $(96.5 \%)$. In addition, the cross-sectional and time series variability in NII is described by ROA $(1.2 \%)$, HST $(7.6 \%)$, NPL $(0.95 \%)$ and lagged-NII (89\%), whilst the variability in DBAG is described by HST $(4.2 \%)$, NII (2.5\%), GDP $(2.6 \%)$ and lagged-DBAG (89.8\%). Similarly, the variations in COM and NIM are explained by NII $(0.5 \%)$ and lagged-COM (99\%); and lagged-NIM $(98 \%)$ and DBAG $(1.1 \%)$ correspondingly. The evidence shows that the one period lag of each variable is the most important factor describing its variations through time and within the cross-section. This notwithstanding, 
the other variables in the system are relevant in describing the variations in the endogenous variables.

For instance, ROA and NII describe about $5.1 \%$ of the variance of NPL; $9.75 \%$ of the variability in NII is explained by ROA, HST and NPL; and about $1.51 \%$ of the variability in ROA are described by DBAG, NII and GDPG. Additionally, $3.4 \%$ of the variance of PNPL is explained by HST and DBAG whilst about $1.78 \%$ of the variance of HST is captured by NII and DBAG. These values are economically meaningful.
Frontier and emerging economy banks

\section{Conclusions}

The study examines the drivers of competition, risk-taking, performance and risk diversification of banks in FEEs. It explores the dynamic relationships among these variables. Additionally, it investigates the influence of banking sector depth and economic performance on the competition, performance, diversification and risk-taking activities of FEE banks.

The study finds that the PNPLs and banking sector depth exert positive effects on competition (HST) whereas non-performing loans and growth in GDP impact banking sector competition negatively. Additionally, improvements in bank performance (net interest margin) and a surge in non-performing loans reduce asset concentration in few banks (increase competition). The results may imply that the expectation of rising competition particularly in periods of economic expansion may drive banks to make more PNPLs. However, as non-performing loans surge, banking sector competition is reduced. In addition, the study finds that bank performance (return on assets) slumps with rising banking sector depth and competition (HST). That is, banks in countries with well-developed and competitive banking sectors are less profitable. Also, the growth in inflation and the PNPLs improve bank performance (net interest margin) although performance is constrained by rising banking sector depth. The paper provides evidence that risk-taking incentives (provisions for non-performing loans) increase with strengthening competition, rising NIM and deepening banking sector depth. Additionally, rising competition, profitability, PNPLs and banking sector depth reduce income diversification. In addition, inflation growth increases income diversification activities. As inflation increases, the likelihood of default may also rise. As a consequence, banks may reduce their focus on interest income and explore other opportunities for improving performance.

The findings from the study have implications for policy and banking practice. The findings suggest that whereas competition is essential for banking sector growth and development, excessive competition may undermine banking sector profitability. Anticompetitive behaviour may lead to increased inefficiency which may consequently undermine banking sector growth. The evidence shows that asset growth may drive up competition and thus improve on efficiency and soundness of the banking sector. Excessive asset growth however, may reduce profitability and diversification activities of FEE banks. Also, lower levels of profitability may lead to higher insolvency risk. Additionally, inadequate diversification opportunities or limited technology to promote diversification may lead to a rise in risk-taking activities and thus undermine banking sector profitability and soundness. Policy that supports sustainable asset growth should be encouraged. That is, policy should dissuade asset growth that is driven by excessive risk-taking. Sustainable asset growth would improve economic activities and drive growth and social welfare enhancement in an economy. In addition, policy should aim at ensuring sufficient level of banking sector competition and not excessive or fierce competition. That is, policy should strike the right balance between competition, performance and stability.

\section{Note}

1. Data on the variables for each country are contained in the Global Financial Development Database. 


\section{AJEB \\ 6,1}

\section{References}

Akter, A., Majumder, M.T.H. and Uddin, M.J. (2018), "Do capital regulations and risk-taking behavior affect bank performance? Evidence from Bangladesh", Asian Economic and Financial Review, Vol. 8 No. 8, p. 1042.

Akter, R., Ahmad, S., Kulsum, U., Hira, N.J., Akhter, S. and Islam, M.S. (2019), "A study on the implementation of Basel III: Bangladeshi perspective", Academy of Strategic Management Journal, Vol. 18 No. 6, pp. 1-10.

Anginer, D., Demirguc-Kunt, A. and Zhu, M. (2014), "How does competition affect bank systemic risk?”, Journal of Financial Intermediation, Vol. 23 No. 1, pp. 1-26.

Barth, J.R., Caprio, G. Jr and Levine, R. (2004), “Bank regulation and supervision: what works best?”, Journal of Financial Intermediation, Vol. 13 No. 2, pp. 205-248.

Berger, A.N. (1995), "The relationship between capital and earnings in banking", Journal of Money, Credit and Banking, Vol. 27 No. 2, pp. 432-456.

Berger, A.N., Hasan, I. and Zhou, M. (2010), "The effects of focus versus diversification on bank performance: evidence from Chinese banks", Journal of Banking and Finance, Vol. 34 No. 7, pp. 1417-1435.

Bikker, J.A. (2010), "Measuring performance of banks: an assessment", Journal of Applied Business and Economics, Vol. 11 No. 4, pp. 141-159.

Boateng, K. (2019), "The relationship between efficiency, productivity and profitability of Ghanaian banks", IOSR Journal of Business and Management (IOSR-JBM), Vol. 21 No. 6, pp. 52-60.

Brissimis, S.N., Delis, M.D. and Papanikolaou, N.I. (2008), "Exploring the nexus between banking sector reform and performance: evidence from newly acceded EU countries", Journal of Banking and Finance, Vol. 32 No. 12, pp. 2674-2683.

Campbell, A. (2007), "Bank insolvency and the problem of nonperforming loans", Journal of Banking Regulation, Vol. 9 No. 1, pp. 25-45.

Canova, F. and Ciccarelli, M. (2013), Panel Vector Autoregressive Models: A Survey, ECB Working Paper, No. 1507, European Central Bank (ECB), Frankfurt.

Claessens, S. and Laeven, L. (2004), "What drives bank competition? Some international evidence", Journal of Money, Credit and Banking, Vol. 36 No. 3, pp. 563-583.

Clarke, G.R., Cull, R., Martinez Peria, M.S. and Sanchez, S.M. (2001), Foreign Bank Entry: Experience, Implications for Developing Countries, and Agenda for Further Research, Policy Research Working Paper, (2698), World Bank.

Craigwell, R. and Maxwell, C. (2006), "Non-interest income and financial performance at commercial banks in Barbados", Savings and Development, Vol. 30 No. 3, pp. 309-328.

Danisman, G. (2018), "Overview of competition in the banking sector", International Journal of Economics, Commerce and Management, Vol. 6 No. 4, pp. 59-71.

Demsetz, H. (1973), "Industry structure, market rivalry and public policy", Journal of Law and Economics, Vol. 16 No. 1, pp. 1-9.

Dickey, D.A. and Fuller, W.A. (1979), "Distribution of the estimators for autoregressive time series with a unit root", Journal of the American Statistical Association, Vol. 74 No. 366a, pp. 427-431.

Fiordelisi, F. and Mare, D.S. (2014), "Competition and financial stability in European cooperative banks", Journal of International Money and Finance, Vol. 45, pp. 1-16.

García-Herrero, A., Gavilá, S. and Santabárbara, D. (2009), "What explains the low profitability of Chinese banks?", Journal of Banking and Finance, Vol. 33 No. 11, pp. 2080-2092.

Ghosh, S. (2014), "Risk, capital and financial crisis: evidence for GCC banks", Borsa Istanbul Review, Vol. 14 No. 3, pp. 145-157.

Goddard, J., Molyneux, P. and Wilson, J.O. (2004), "The profitability of European banks: a crosssectional and dynamic panel analysis", The Manchester School, Vol. 72 No. 3, pp. 363-381. 
González, L.O., Razia, A., Búa, M.V. and Sestayo, R.L. (2017), “Competition, concentration and risk taking in Banking sector of MENA countries", Research in International Business and Finance, Vol. 42, pp. 591-604.

Guidara, A., Soumaré, I. and Tchana, F.T. (2013), "Banks' capital buffer, risk and performance in the Canadian banking system: impact of business cycles and regulatory changes", Journal of Banking and Finance, Vol. 37 No. 9, pp. 3373-3387.

Gupta, A.D. and Moudud-Ul-Huq, S. (2020), "Do competition and revenue diversification have significant effect on risk-taking? Empirical evidence from BRICS banks", International Journal of Financial Engineering, Vol. 7 No. 01, p. 2050007.

Holtz-Eakin, D., Newey, W. and Rosen, H.S. (1988), "Estimating vector autoregressions with panel data”, Econometrica: Journal of the Econometric Society, Vol. 56 No. 6, pp. 1371-1395.

Jiménez, G., Lopez, J.A. and Saurina, J. (2013), "How does competition affect bank risk-taking?”, Journal of Financial Stability, Vol. 9 No. 2, pp. 185-195.

Kasman, A. and Carvallo, O. (2014), "Financial stability, competition and efficiency in Latin American and Caribbean banking", Journal of Applied Economics, Vol. 17 No. 2, pp. 301-324.

Koivu, T. (2012), "Monetary policy, asset prices and consumption in China”, Economic Systems, Vol. 36 No. 2, pp. 307-325.

Li, S. (2019), "Banking sector reform, competition, and bank stability: an empirical analysis of transition countries", Emerging Markets Finance and Trade, Vol. 55 No. 13, pp. 3069-3093.

Liu, H., Molyneux, P. and Nguyen, L.H. (2012), "Competition and risk in the South East Asian commercial”, Applied Economics, Vol. 44 No. 28, pp. 3627-3644.

Maji, S.G. and Hazarika, P. (2018), "Capital regulation, competition and risk-taking behavior of Indian banks in a simultaneous approach", Managerial Finance, Vol. 44 No. 4, pp. 459-477.

Majumder, M.T.H. and Li, X. (2018), "Bank risk and performance in an emerging market setting: the case of Bangladesh", Journal of Economics, Finance and Administrative Science, Vol. 23 No. 46, pp. 199-229.

Majumder, M.T.H. and Uddin, M.J. (2017), "The determinants of profitability of nationalised banks in Bangladesh", International Journal of Economics and Business Research, Vol. 13 No. 4, pp. 335-348.

Merin, M.A. (2016), "Determinants of bank profitability in Ethiopia: a case study of private commercial banks", Research Journal of Finance and Accounting, Vol. 7 No. 7, pp. 28-43.

Mlambo, K. and Ncube, M. (2011), "Competition and efficiency in the banking sector in South Africa", African Development Review, Vol. 23 No. 1, pp. 4-15.

Moshirian, F. and Wu, Q. (2012), "Banking industry volatility and economic growth", Research in International Business and Finance, Vol. 26 No. 3, pp. 428-442.

Perry, P. (1992), “Do banks gain or lose form inflation”, Journal of Retail Banking, Vol. 14 No. 2, pp. 25-30.

Petria, N., Capraru, B. and Ihnatov, I. (2015), "Determinants of banks' profitability: evidence from EU 27 banking systems", Procedia Economics and Finance, Vol. 20, pp. 518-524.

Rahman, M.M., Hamid, M.K. and Khan, M.A.M. (2015), "Determinants of bank profitability: empirical evidence from Bangladesh", International Journal of Business and Management, Vol. 10 No. 8, p. 135.

Saif-Alyousfi, A.Y., Saha, A. and Md-Rus, R. (2020), "The impact of bank competition and concentration on bank risk-taking behavior and stability: evidence from GCC countries", The North American Journal of Economics and Finance, Vol. 51, p. 100867.

Sarkar, S. and Sensarma, R. (2016), "The relationship between competition and risk-taking behaviour of Indian banks", Journal of Financial Economic Policy, Vol. 8 No. 1, pp. 95-111.

Schaeck, K. and Cihák, M. (2014), "Competition, efficiency, and stability in banking", Financial Management, Vol. 43 No. 1, pp. 215-241.

Frontier and emerging economy banks (1) 
AJEB

6,1

Schaeck, K. and Cihak, M. (2012), "Banking competition and capital ratios", European Financial Management, Vol. 18 No. 5, pp. 836-866.

Scott, J.A. and Dunkelberg, W.C. (2010), "Competition for small firm banking business: bank actions versus market structure”, Journal of Banking and Finance, Vol. 34 No. 11, pp. 2788-2800.

Soedarmono, W., Machrouh, F. and Tarazi, A. (2013), "Bank competition, crisis and risk taking: evidence from emerging markets in Asia", Journal of International Financial Markets, Institutions and Money, Vol. 23, pp. 196-221.

Tabak, B.M., Fazio, D.M. and Cajueiro, D.O. (2012), "The relationship between banking market competition and risk-taking: do size and capitalization matter?", Journal of Banking and Finance, Vol. 36 No. 12, pp. 3366-3381.

Tan, Y. (2016), "The impacts of risk and competition on bank profitability in China", Journal of International Financial Markets, Institutions and Money, Vol. 40, pp. 85-110.

Tan, Y. (2018), "The impacts of competition and risk on profitability in Chinese banking: evidence from Boone indicator and stability inefficiency", Annals of Economics and Finance, Vol. 19 No. 2.

Tan, Y. and Floros, C. (2012), "Bank profitability and GDP growth in China: a note", Journal of Chinese Economic and Business Studies, Vol. 10 No. 3, pp. 267-273.

Tan, Y. and Floros, C. (2014), "Risk, profitability, and competition: evidence from the Chinese banking industry", The Journal of Developing Areas, Vol. 48 No. 3, pp. 303-319.

Zhao, T., Casu, B. and Ferrari, A. (2010), "The impact of regulatory reforms on cost structure, ownership and competition in Indian banking", Journal of Banking and Finance, Vol. 34 No. 1, pp. 246-254.

Zheng, C., Das Gupta, A. and Moudud-Ul-Huq, S. (2017), "Do market competition and development indicators matter for banks' risk, capital, and efficiency relationship?", International Journal of Financial Engineering, Vol. 4 No. 02n03, p. 1750027.

\section{Further reading}

Clarke, G., Cull, R., Peria, M.S.M. and Sanchez, S.M. (2003), "Foreign bank entry: experience, implications for developing economies, and agenda for further research", The World Bank Research Observer, Vol. 18 No. 1, pp. 25-59.

\section{Corresponding author}

Nicholas Addai Boamah can be contacted at: addaianas@yahoo.com

For instructions on how to order reprints of this article, please visit our website:

www.emeraldgrouppublishing.com/licensing/reprints.htm

Or contact us for further details: permissions@emeraldinsight.com 